\title{
Components of woody-tissue respiration in Abies amabilis
}

\author{
D.G. Sprugel \\ College of Forest Resources, AR-10, University of Washington, Seattle, WA 98195, U.S.A.
}

\section{Introduction}

Although respiration has long been recognized as an important component of plant energy budgets, whole-plant respiration under field conditions has rarely received the attention one might expect for a process that may consume up to $80 \%$ of gross primary production (Whittaker, 1975). As a result, there are some significant inconsistencies among the 'wellknown' facts about respiration. Kramer and Kozlowski (1979) noted that stem respiration is concentrated in the cambial region and inferred that : "it would be expected that a forest stand consisting of a small number of trees of large diameter would have a more efficient ratio of photosynthesis to respiration than a stand of the same basal area composed of trees of smaller diameter". This suggests that the surface area of a tree or stand is the primary determinant of its woody-tissue respiration. Kira and Shidei (1967), however, thought that woody-tissue respiration was primarily determined by biomass, saying : "the biomass of woody organs... increases monotonously with age, and hence the amount of organic matter consumed by the respiration of woody organs might follow the same course of increase". The purpose of this study was to determine what morphological and physiological factors are correlated with respiration rate in young Abies amabilis trees, and to estimate annual woody-tissue respiration by component for a $30 \mathrm{yr}$ old A. amabilis stand.

\section{Study site and Methods}

The site for this study was a $30 \mathrm{yr}$ old $A$. amabilis (Pacific silver fir) stand about $65 \mathrm{~km}$ southeast of Seattle, WA, in the Findley Lake research area on the City of Seattle's Cedar River watershed. The trees range from 1 to $6 \mathrm{~m}$ in height, with diameters from $<1$ to $14 \mathrm{~cm}$. Respiration measurements were made on 12 different trees in each year of the study, ranging from 1.25 to $5.5 \mathrm{~m}$ in height and from 1.8 to $10.0 \mathrm{~cm}$ in diameter. Two bole locations and 2 branch locations were selected on each tree. The respiration rate at each location was measured on 5 dates in the summer and fall of 1985 to determine general respiration patterns and biweekly in 1986 to provide a more complete set of measurements for estimating total annual respiration.

Respiration was measured with temporary clamp-on cuvettes made from acrylic (plexiglas) tubing capped at both ends and cut in half lengthwise so that the cuvette could be 
clamped around a branch (illustrated in Sprugel and Benecke (1989), Fig. 6). $\mathrm{CO}_{2}$ exchange was measured in an open flow-through system using an ADC LCA-1 portable IRGA. Chambers were shaded to prevent overheating but were otherwise maintained under ambient conditions. Tissue temperatures were determined at the time of each measurement using thermocouples installed under the bark. All measurements were converted to $15^{\circ} \mathrm{C}$ using a $Q_{10}$ of 2.0. This value was based on $24 \mathrm{~h}$ monitoring of several bole and branch sections and is consistent with previous studies (cf. Berry and Raison, 1981).

After the final respiration measurement, the sample trees were cut down and returned to the laboratory for analysis. Basal diameter, length, height and age of every living branch were measured. In 1986, the leader length and weight of new growth were also measured for each branch. Discs were cut from the bole every $0.5 \mathrm{~m}$, starting at $0.25 \mathrm{~m}$, and from the center of each respiration measurement section if the site did not coincide with a $0.5 \mathrm{~m}$ cut. For each disc, the current ring thickness and sapwood thickness were measured.

In analyzing the morphological and physiological correlates of respiration, it is particularly important to distinguish between growth respiration, the cost of producing new tissues, and maintenance respiration, the energy required to keep living cells alive. The most common method for doing this in trees, and the one that was used in this study, is to assume that measurements taken after the growing season represent maintenance respiration rates. Growth respiration for growing season measurements is then estimated by subtracting maintenance respiration from total respiration. Sprugel and Benecke (1989) discuss the validity of this method and possible problems with it.

For each sampling date, regressions were developed to predict bole growth and maintenance respiration from annual ring growth and sapwood volume. These regressions were used to extrapolate from measurements on the sample sections to the whole tree. Similar equations were used to estimate total branch respiration for each tree. Estimates of total respiration by component for each tree for each sampling date were then regressed against tree diameter. In 1986, these equations were combined with diameter measurement from permanent plots (Grier et al., 1981) and temperature records from a nearby weather station to estimate total annual woody-tissue respiration for the stand.

\section{Results}

\section{Bole respiration}

When September bole respiration rates were regressed against sample surface area, sapwood volume and current ring volume, sapwood volume was the only useful predictor of respiration. This result was found in both years of the study, and has two important implications. First, the fact that September respiration was not correlated with current ring volume (i.e., annual wood production) suggests that growth respiration is negligible in September; that is, that by September the remaining respiration is almost entirely maintenance. Second, the fact that maintenance respiration is correlated with sapwood volume, but not with surface area, indicates that cambial maintenance respiration (which should be correlated with surface area) is also negligible and that virtually all of the maintenance respiration in an A. amabilis stem is due to sapwood.

Growth respiration for each measured section on each of the growing-season sampling dates was estimated by subtracting the September (maintenance) respiration for that section from the total measured respiration. Regression analysis showed that growth respiration thus estimated was well correlated with growth rates (as indicated by annual ring growth measured at the end of the year) and was rarely correlated with anything else.

\section{Branch respiration}

It might be expected that since the same components of respiration should operate in branches and boles, the equations developed for predicting bole respiration should be equally useful for predicting branch respiration. This is not the case; 
Table I. Estimated woody-tissue respiration and net production for a $\mathbf{3 0}$ yr old $A$. amabilis stand in the Cascade Mts., WA, U.S.A.

\begin{tabular}{lll}
\hline & \multicolumn{2}{l}{ Stand totals } \\
\cline { 2 - 3 } & $g \mathrm{CO}_{2} \cdot m^{-2} \cdot y r^{-1}=$ & 1.9 \\
\hline $\begin{array}{l}\text { Respiration } \\
\text { bole growth } \\
\text { bole maintenance } \\
\text { branches (total) }\end{array}$ & 355 & 1.1 \\
& 185 & 1.9 \\
total aboveground & 355 & 4.9 \\
$\begin{array}{l}\text { Net production } \\
\text { bole wood } \\
\text { total aboveground }\end{array}$ & 900 & \\
\hline
\end{tabular}

a Grier et al., 1981.

branch respiration was much greater than would be predicted by the bole equations, typically by at least a factor of 2 but sometimes much more. The degree of underestimation was greatest in June (averaging $4.5 \mathrm{x}$ ) and decreased through the year, to $2.1 \times$ in September. Either it takes a great deal more energy to produce and maintain a given volume of branch tissue than it does for bole tissue, or branch respiration includes large contributions from other components in addition to those important in boles.

Multiple regression analysis showed that, unlike bole respiration, branch respiration was not correlated with sapwood volume and not particularly well correlated with growth ring thickness. Moreover, unlike bole respiration, branch respiration was significantly and positively correlated with branch height. In fact, branch height was a better predictor of branch respiration than either current ring growth or sapwood volume.

Because of the difficulty of estimating total branch growth and poor correlations between branch growth and measured respiration, no attempt was made to separate branch respiration into growth and maintenance components. Instead, for each sampling date, equations were developed to predict total respiration for an individual branch from branch surface area and volume and leader length.

Total bole and branch respiration for the stand are shown in Table I. It is clear that woody-tissue respiration can be a major component of the stand's overall energy budget, even in a young stand with relatively small total biomass.

\section{Conclusions}

The 2 major components of bole respiration were growth respiration and sapwood maintenance respiration. There was no evidence of significant cambial maintenance respiration. Thus biomass is likely to be more important than surface area in determining stand respiration.

Respiration in branches was much greater than in boles of comparable volume and growth rates and was significantly correlated with leader growth.

Total aboveground woody-tissue respiration for 1986 was estimated at $900 \mathrm{~g}$ $\mathrm{CO}_{2} \cdot \mathrm{m}^{-2} \cdot \mathrm{yr}^{-1}$, equivalent to about $5 \mathrm{t} \cdot \mathrm{ha}^{-1}$ 
of dry matter - substantially greater than bole wood production ( $\left.3.4 \mathrm{t} \cdot \mathrm{ha}^{-1} \cdot \mathrm{yr}-1\right)$ and not much less than total above ground net production (6.5-7 tha $\left.\mathrm{a}^{-1} \cdot \mathrm{yr}^{-1}\right)$.

\section{References}

Berry J.A. \& Raison J.K. (1981) Responses of macrophytes to temperature. In: Encyclopedia of Plant Physiology 12A. Physiological Plant Ecology I. (Lange O.L., Nobel P.S., Osmond C.B. \& Ziegler H., eds), Springer-Verlag, Berlin, pp. 277-338

Grier C.C., Vogt K.A., Keyes M.R. \& Edmonds R.L. (1981) Biomass distribution and above- and belowground production in young and mature Abies amabilis zone ecosystems of the Washington Cascades. Can. J. For. Res. 11, 155-167

Kira T. \& Shidei T. (1967) Primary production and turnover of organic matter in different forest ecosystems of the western Pacific. Jpn. J. Ecol. 17, 70-87

Kramer P.J. \& Kozlowski T.T. (1979) In: Physiology of Woody Plants. Academic Press, New York, p. 240

Sprugel D.G. \& Benecke U. (1989) Woodytissue respiration and photosynthesis. In: Methods and Approaches in Tree Ecophysiology. (Lassoie J.P. \& Hinckley T.M., eds.), CRC Press, Boca Raton, FL

Whittaker R.H. (1975) In: Communities and Ecosystems. 2nd edn., Macmillan, New York, p. 205 